\title{
On the relationship between intra group conflict and group performance: Evidence from Telecom Sector of Pakistan
}

\author{
Muhammad, NASEER, \\ Mohammad Ali Jinnah University Islamabad \\ naseerahmadcust@gmail.com \\ Haleem, FAZAL, \\ Abdul Wali Khan University Mardan \\ haleemfazal@gmail.com
}

\begin{abstract}
The current study investigates the link between Intra Group Conflict (Task Conflict, Relationship Conflict) and Group Performance of the employees in the Telecom sector of Pakistan. Employees' performances are improved by harmony, friendly environment and lack of conflict in an organization. To find out the practicality of these assertions, 200 questionnaires were distributed among employees of five main mobile telecom companies namely Telenor, Mobilink, Ufone, Zong and Warid at their head offices. 122 questionnaires were received back that resulted in 61\% response rate. The paper addressed the extent of employees' perception about Task Conflict and Relationship Conflict in their groups and also investigated that how these types of Intra-group conflict were linked to the overall performance of their groups. A theoretical model was developed to test these hypotheses. For the measurement of intra group conflict (Task conflict, relationship conflict) and group performance two valid and reliable instruments were used. Furthermore for analysis of these data Correlation and regression were used. The result of the study showed significant positive relationship between task conflict and group performance. However, negative association was found between relationship conflict and group performance. At the end, conclusion, limitations, and future research bearings are likewise highlighted.
\end{abstract}

Keywords: Conflict on task, Conflict on relationship, Group performance, Telecom sector.

JEL Classification: M5.

\section{Introduction}

This study investigates the link between intragroup conflict and group performance in Telecom sector of Pakistan. Human resource is an integral part of an organization. Team or group members work together to accomplish organization's goals and objectives. However, these teams have different 
cultures, backgrounds, ideas and different agendas. These differences create conflict among these teams/groups. Boulding (1963) posits that conflict is the combination of inconsistencies, contradictory wishes, or wants beyond reconciliation. Moreover, Karatepe and Tekinkus (2006) argue that organizational conflict reflects the mismatch between objectives of individuals and that of organization that ultimately leads to adverse effects on organizational performance. According to Zepeda (2006), it is hard to escape conflict in an organization because employees both inside and outside of an organization have different goals and objectives. Conflict is a vital part of life where people compete for resources, authority, safety and jobs.It is difficult to manage the conflict for many reasons such as it produces ill-feelings when individual/team feels debilitated. Thus, it leads to pressure and tension that results in initiating the reaction of outrage and fight.

Conflicts that exist inside groups or divisions are known as Intra group conflict. The level of intra group conflict increases with the increase in the lack of coordination between individual teams. Moreover, conflict among groups is not necessarily a bad thing as it enables each group to cooperate and improve performance (Van de Vliert and Kabanoff 1990; Pondy 1969). Similarly, Debreu and Van de Vliert (1997) explain that intra group conflict occurs when emotions between two parties reach to extreme as a result they start to show hostility orally as well as physically. However extreme level of trust, an esteem introduction of conflict, and work force participation play their role in lowering down the intra-group conflict. Similarly Pererson and Behfar (2003) study shows that intra group conflict can be turned into positive results by facilitating meetings and discussions among colleagues. According to Simons and Peterson (2000), Jehn for the first time divided intra-group conflict in two kinds: Task conflict and relationship or interpersonal conflict. According to Jehn (1995), task conflict means different views, ideas, and thoughts of group members toward the task. Moreover, he explained thatrelationship conflict referred to personality clashes that were caused by animosity, tension, and annoyance. In additionresearch study also explained that relationship conflict namely anxiety, affiliation, and hatred decreases efficiency and performance of team members. On the other hand, task conflict supported the team members to clear their views, ideas, and concepts and accept decisions toward the task to enhance the team members' performance (Jehn, 1995; Amason, 1996; Pelled, 1999). Finally, the results of this study help policy makers and top management to handle conflicts which adversely affect the performance of the workers as well as boost those sources of conflict that leads to creativity, effectiveness and group outcome to improve the firms' performance. 


\section{Literature Review}

\section{Intragroup Conflict:}

According to Boulding (1963), conflict arises due to strong aversion, different perceptions and different opinions among individuals/teams. Mack (1965) defines conflict as the incompatibility of objectives between two or more parties. As per Thomas (1976), conflict is a process which incorporates discernments, feelings, practices and results of two gatherings and "starts when one gathering sees that alternate has disappointed.As indicated by Tjosvold (2006), there are four major conflicts namely interpersonal, inter-group, interorganizational, and intra-group conflict. To begin with interpersonal conflict, it happens when one party interferes of in the affairs of other party as well as harms their goals and objectives. On the other hand, a conflict that occurs between two parties, such as two or more teams/groups, of the same organization is referred to inter-group conflict. Similarly, a conflict is referred as inter-organizational conflict if it occurs across the organizations. Moreover Intragroup conflict portrays a circumstance in which group individuals hold discrepant perspectives and have diverse feelings, states of mind, learning or have relational contrary qualities with each other (Jehn,1994). A few sources and kinds of contradictions and tensions were reported in the literature, beginning with the shortage of assets, full of feeling states (stress and tensions) or subjective states contrast in discernments, assessments and attitudes (Pondy, 1967). Concerning the distinctive kinds of conflicts that can show up in a group and in spite of the various marks found in literature, most researchers recognize two types of conflicts initially task related and then relationship conflict (Rahim, 2002; Dimas, Lourenco, Miguez, 2005; Dimas, 2007).

\section{Task conflict and group performance:}

Task conflict increases performance due to different points of view and various understanding, but it also causes interference with an agreement as well as diverts workers from their goals and objectives (Amason, 1996; Hambrick, Cho, and Chen, 1996; Amason and Schweiger, 1994). As per Jehn (1995), task conflict increases group performance, quality of decisions, and acceptance of decisions as well as satisfaction of the team members. Similarly, West and Anderson (1996) state that task conflict is positively correlated with innovation as well as quality of ideas. Similarly Jehn (1999) also found that task conflict helped productive discussion between team members. Furthermore, it also increases acceptance of group decisions (Amason, 1996), and causes prevention of group thinking (Turner and Pratkanis, 1994). In addition, the task conflict leads to better leadership, enhanced profitability, creating and sharing new ideas, 
enhanced correspondence, as well as resolving issues (Rispens, 2009). However some researchers found that task conflict decreases satisfaction, unity and increases anxiety (e.g. Jehn and Mannix, 2001; Friedman et al., 2000). Similarly De Dreu and Weingart's meta-study found that task conflict may be negative as relationship conflict because conflict increases discrepancies of team members as well as quantity and intensity of different opinions.

In the light of above literature the following hypothesis is derived.

Hypothesis 1: There will be positive relationship between task conflict and group performance in the telecom sector of Pakistan.

\section{Relationship conflict and group performance:}

Relationship conflict results in unwanted consequences for group performance because it spoils the relationship between individuals as well as experts. Likewise, it creates tension between colleagues (Wall and Callister, 1995; Hackman and Morris, 1975). In this connection, De and Van de (2001) found that relationship conflict encounters tension and at time squabbles among people because of emotional elements. Emotional elements could lead to disparity of conviction, conviction of principles, ordeals and dissatisfaction among people. Such circumstances create opposing response and relations among people within organization. As an outcome, relationship conflict adversely affects group performance (Hjert $\varnothing$, and Kuvaas, 2009). Relationship conflict leads to fostering negative workplace environment and put antagonistic effects on working conditions. Individuals end up troubled and hold their candid collaboration as per their capacity. Relationship conflict negatively affects group performance, group fulfillment and responsibility with the gathering, for the reasons, it inflates pressure and tension and hence it confines the data handling capacities of the group members (Jehn, 1995). Numerous researchers infer that task conflict is generally useful and functional, though relationship conflict is useless and dysfunctional (Rollinson, 2002; Robbins, 2000; McShane and Von Glinow, 2000). In the light of above literature the following hypothesis is derived.

Hypothesis 2: There will be negative relationship between relationship conflict and group performance in the telecom sector of Pakistan.

\section{Theoretical Framework}

The theoretical framework of this research consists of two classes of variables, which is the independent variables and dependent variable. Based on the review of literature, the conceptual framework is devised with dependent variables (group performance) and independent variables (intra-group conflict). 
Figure 1: Theoretical Framework of intra group conflict and group performance.

Independent variables

Dependent variable

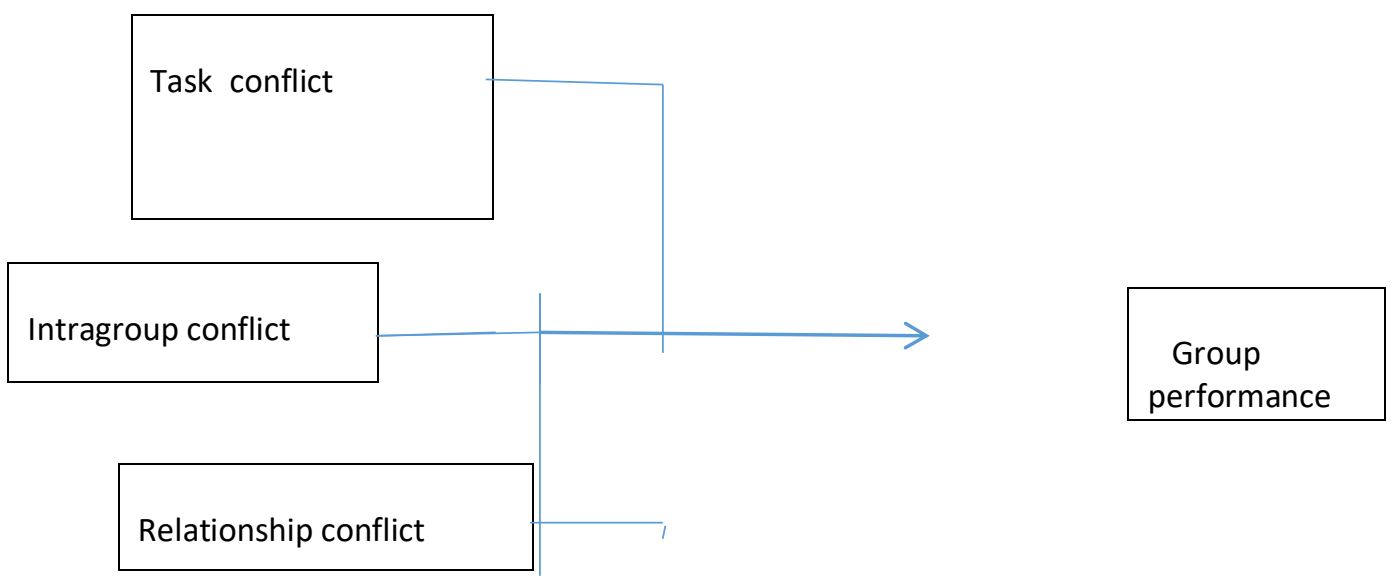

Source: Authors own research

\section{Methodology}

\section{Participants}

The participants of the study include employees from Head Offices of Telecom Companies i.e. Telenor, Mobilink, Ufone, Zong and Warid, in Islamabad and Rawalpindi regions. There were total of 200 questionnaires distributed among the respondents; out of 122 questionnaires were returned and the response rate was $61 \%$. The participants were male and female managers, supervisors and junior level of employees in the organizations. In terms of age, the employees were categorized into younger employees (15-25), middle age employees (26-35), and older employees above 36 years. From gender perspective, 92 and 30 males and females respondents participated. Similarly, educational level of respondents was assessed in terms of intermediate, bachelor and master employees.

\section{Questionnaire:}

Different forms of Intra group conflict were measured using the original 28-items measuring scale developed by Jehn (1995). Data was collected through questionnaires and using a 5-point Likert scale where 1 labeled 'strongly disagree' and 5 'strongly agree'. Jehn (1995) reported the reliability of two subscales of intra group conflict (Task conflict and relationship conflict) within range of 0.72 to 0.77 . Furthermore group performance was measured using 8-items 
measuring scale developed by Ancona and Caldwell (1992) and the respective Cronbach Alpha was 0.73 .

\section{Results}

The purpose of this research is to examine the association between intragroup conflict and group performance in telecom sector of Pakistan. For this purpose, reliability, correlation, and regression tests were performed and results are summarized below.

\section{Reliability Analysis}

Using SPSS (17 version) reliability tests were conducted to find out the internal consistency of the instruments employed for data collection. The internal reliability of subcomponents of intra group conflict and group performance are depicted in table 1.

Table 1Alpha Reliabilities of Variables

Variables NameN of ItemsCronbach's Alpha

$\begin{array}{lcc}\text { Task conflict } & 5 & 0.70 \\ \text { Relationship conflict } & 5 & 0.73 \\ \text { Group performance } & 8 & 0.75\end{array}$

Source: Authors own research

Table 1 indicates high internal reliability coefficient for all scales used, the alpha values 0.70 and 0.73 for task conflict and relationship conflict and .75 for group performance that are quite acceptable in social science research.

\section{Correlations}

Table 2 shows Correlation between intra group conflict and group performance.

Table 2: Correlation Analysis

\begin{tabular}{lcll}
\hline & Task conflict & Relationship conflict & Group performance \\
Task conflict & 1 & & \\
\hline
\end{tabular}

Relationship conflict $.239 * * \quad 1$

Group performance $.320 * * \quad-.213 * * 1$

$* *$ Correlation is significant at the 0.01 level (2-tailed).

* Correlation is significant at the 0.05 level (2-tailed). 
Table 2 depicts the coefficient of correlation between task conflict and group performance. It indicates that there is strong and significant positive correlation between task conflict and group performance with correlations coefficient of 0.32 and $p$-value of 0.01 . Furthermore, the coefficient of correlation between relationship conflict and group performance is -0.21 with $p$ value of 0.01 that indicates significant but negative correlation between relationship conflict and group performance.

\section{Regression Analysis}

The impact of intra-group conflict on group performance was assessed with regression analysis. The results of regression analysis are depicted in table \# 3.

Table 3 Regression Statistics

\begin{tabular}{|c|c|c|c|c|}
\hline Predictors: & \multicolumn{4}{|c|}{ Dependent Variable: Group performance } \\
\hline \multirow[t]{3}{*}{ Beta( $\beta)$} & t - valuep-value & & & \\
\hline & Task conflict & 0.148 & 1.639 & 0.038 \\
\hline & $\begin{array}{l}\text { Relationship conflict } \\
0.20\end{array}$ & -0.128 & -0.698 & 0.012 \\
\hline
\end{tabular}

The values of intercepts with respective $t$-values and $p$-values are depicted in table \# 3 . The results indicate that Task Conflict has positive and significant impact on group performance $(p<.05 ; \beta=.148)$ that extend support for accepting the hypothesis H1. Furthermore, Relationship conflict $(p<.05 ; \beta=-$ .128) also has significant but negative impact on group performance extending support for accepting the hypothesis $\mathrm{H} 2$.

\section{Discussion and Conclusions}

Research was carried out to examine the relationship between intragroup conflict (task conflict, relationship conflict) and group performance. It is concluded that relationship of task conflict and group performance is positive and significant while the relationship of relationship conflict and group performance is negative but significant. The result of first grounding hypothesis is that there is positive relationship between task conflict and group performance in telecom sector of Pakistan. The results of the study reinforces 
the prior results of researchers (e.g. Schweiger, Sandberg, \& Ragan, 1986; Hambrick, Cho, \& Chen, 1996; Amason, 1996; Amason \& Schweiger, 1994; Schweiger et al., 1989; Jehn, 1995; West and Anderson, 1996; Turner and Pratkanis, 1994; Rispens, 2009).

The results of second hypothesis of relationship conflict is negatively associated with group performance is directly linked with the results of many researchers (e.g. Hjertø, \& Kuvaas, 2009; Kankanhalli, Tan and Wei, 2007; Rollinson, 2002; De Dreu, and Van de, 2001; Robbins, 2000; McShane \& Von Glinow, 2000; Hackman \& Morris, 1975; Wall \& Callister, 1995; Robbins, 1974; Jehn, Chadwick and Thatcher, 1997 ).

This research is helpful for top management, policy makers as well as literature. It is imperative for top management and policy makers to minimize negative effects of conflicts among workers and keep up a level of conflict to a degree where conflict increases group performance in organization. Similarly from scholarly point of view, it is a contribution in the literature. Furthermore, cross sectional study was conducted rather than longitudinal study which decreases the generalizability and reliability of the outcomes. Therefore, longitudinal research is needed to increase the generalizability and reliability of outcomes. In addition the present study was quantitative in nature; therefore, the outcome can be enhanced by including subjective components and analyzing information through mixed strategy approach.

\section{References}

[1] Amason, A.C. (1996), "Distinguishing the effects of functional and dysfunctional conflict on strategic decision making: resolving a paradox for top management teams", Academy of Management Journal, Vol. 39, pp. 123-48

[2] Amason, A., \& Schweiger, D. M. 1994. Resolving the paradox of conflict, strategic decision making, and organizational performance. International Journal of Conflict Management, 5: 239-253

[3] Ancona, D.G. and Caldwell, D.F. (1992b), "Demography and design: predictors of new product team performance", Organization Science, Vol. 3 No. 3, pp. 321-41

[4] Appelbaum, S. H., Shapiro, B., \& Elbaz, D. (1998). The management of multicultural group conflict. Team Performance Management: An International Journal, 4(5), 211234.

[5] Boulding, K. 1963. Conflict and defense. New York: Harper \& Row.

[6] Debreu C K W and Van de Vliert E (1997), Using conflict in organizations, SAGE, pp 101-115, London

[7] De Dreu, C.K.W., Van de Vliert, E. M. (2001). Minority dissent and tem innovation: The importance of participation decision making. Journal of applied Psychology, 86, pp1191-1201. 
[8] De Dreu, C.K.W. and Weingart, L.R. (2003), "Task versus relationship conflict: a meta-analysis", Journal of Applied Psychology, Vol. 88, pp. 741-9

[9] Dimas, I. C. D. (Re) pensar o conflito intragrupal: níveis de desenvolvimento e eficácia. 2007. Dissertação (Mestrado em Psicologia Organizacional e do Trabalho)Faculdade de Psicologia e Ciências da Educação, Universidade de Coimbra, Coimbra, 2007

[10] Dimas, I. D.; Lourenco, P. R.; Miguez, J.(2005). Conflitos e desenvolvimento nos grupos e equipas de trabalho - uma abordagem integrada. Psychologica, Coimbra, v. 38, p. 103-119.

[11] Friedman, R.A., Tidd, S.T., Currall, S.C. and Tsai, J.C. (2000), "What goes around comes around: the impact of personal conflict styles on work conflict and stress", International Journal of Conflict Management, Vol. 11, pp. 32-55

[12] Hackman, J. R., Morris, C. G. (1975). Group task, group interaction process, and group performance effectiveness: a review and proposed integration, in Berkowitz, L. (Eds), Advances in Experimental Social Psychology, Academic Press, San Diego, CA, Vol. 8, pp.45-99

[13] Hambrick, D., Cho, T., \& Chen, M. 1996. The influence of top management team heterogeneity on firms' competitive movers. Administrative Science Quarterly, 41: 659-684.

[14] Hjert $\varnothing$, K. B., \& Kuvaas, B. (2009). Development and empirical exploration of an extended model of intra-group conflict. International Journal of Conflict Management, 20(1), 4-30.

[15] Jehn, K.A. Enhancing effectiveness: An investigation of advantages and disadvantages of value based intragroup conflict. Int. J. Conflict Manag. 1994, 5, 223-238.

[16] Jehn, K.A. (1995). A multimethod examination of the benefits and detriments of intragroup conflict. Administrative Science Quarterly, Vol. 40, pp. 256-82.

[17] Jehn, K.A. (1997). A qualitative analysis of conflict types and dimensions in organizational groups. Administrative Science Quarterly, Vol. 42. No.3, pp.530-57.

[18] Jehn, K. A., Chadwick, C., Thatcher, S. M. B. (1997). To agree or not to agree: the effects of value congruence, individual demographic dissimilarity, and conflict on workgroup outcomes. The International Journal of Conflict Management, Vol. 8, pp.287-305.

[19] Jehn, K., Northcraft, G. and Neale, M.A. (1999), "Why difference makes a difference: a field study of diversity, conflict and performance in work group", Administrative Science Quarterly, Vol. 44, pp. 741-63.

[20] Jehn, K.A. and Mannix, E. (2001), "The dynamic nature of conflict: a longitudinal study of intragroup conflict and group performance", Academy of Management Journal, Vol. 44, pp. 238-51

[21] Kankanhalli, A., Tan, B. C. Y. \& Wei, K. K. (2007). Managing Conflict in Global Virtual Teams. Journal of Management Information Systems, Volume 24.

[22] Mack, R. W. (1965). The Components of Social Conflict. Social Problems, Vol. 22, No. 4, pp. 388-397.

[23] McShane, S. L., \& Von Glinow, M. (2000). Organizational behavior. New York: McGraw-Hill.

[24] Pelled, L.H., Eisenhardt, K.M. and Xin, K.R. (1999), "Exploring the black box: an analysis of work group diversity, conflict, and performance", Administrative Science Quarterly, Vol. 44, pp. 1-28. 
[25] Peterson R S and Behfar K J (2003), "The dynamic relationship between performance feedback, trust, and conflict in groups: a longitudinal study", Organizational Behavior and Human Decision Processes, New Jersey

[26] Pinkly, R. L.(1990). Dimensions of conflict frame: disputant interpretations of conflict. Journal of Applied Psychology, Washington, DC, v. 75, p. 117-126

[27] Pondy, L.R. Organizational conflict: Concepts and models. Admin. Sci. Q. 1967, 12, 296-320.

[28] Pondy L R (1969), "Varieties of organizational conflict," Administrative Science Quarterly, pp. 499-505, USA

[29] Rahim, M. A.(2001). Managing conflicts in organizations. Westport: Quorum Books

[30] Rahim,M.A.(2002) Toward a theory of managing organizational conflict. The International Journal of Conflict Management, Bingley, UK, v. 13, n. 3, p. 206-235

[31] Rispens, S. (2009). Do fights prohibit helping? The influence of task interdependence and conflict norms on helping behavior during task conflict. International Journal of Conflict Management, 20(2), 158-172.

[32] Robbins, S. (1974). Managing Organizational Conflict", Prentice-Hall, Englewood Cliffs, NJ

[33] Robbins, S. P. (2000). Managing organizational conflict: A nontraditional approach (9th ed.). Englewood Cliffs, NJ: Prentice Hall

[34] Rollinson, D. (2002). Organisational behavior. Boston: Addison Wesley

[35] Schweiger, D., Sandberg, W., \& Ragan, J. 1986. Group approaches for improving strategic decision making: A comparative analysis of dialectical inquiry, devil's advocacy, and consensus approaches to strategic decision making. Academy of Management Journal, 29: 51-71.

[36] Schweiger, D., Sandberg, W., \& Rechner, P. 1989. Experiential effects of dialectical inquiry, devil's advocacy, and consensus approaches to strategic decision making. Academy of Management Journal, 32: 745-772.

[37] Thomas, k. w. Conflict and conflict Management. In: Dunnette, M. D. (Ed.). Handbook of industrial and organizational psychology. Chicago: Rand McNally, 1976. p. 889-935.

[38] Tjosvold, D. (2006). Defining conflict and making choices about its management: Lighting the dark side of organizational life. International Journal of Conflict Management, 17(2), 87-95.

[39] Turner, M.E. and Pratkanis, A. (1994), "Social identity maintenance prescriptions for preventing groupthink: reducing identity protection and enhancing intellectual conflict", International Journal of Conflict Management, Vol. 5, pp. 254-70.

[40] Van de Vliert E and Kabanoff B (1990), Toward theory-based measures of conflict management, Pearson Education, New York, pp 199.-209

[41] Wall, J. A., Callister, R. R. (1995). Conflict and its management. Journal of Management, Vol. 21, pp.515-58.

[42] West, M.A. and Anderson, N.R. (1996), "Innovation in top management teams", Journal of Applied Psychology, Vol. 81, pp. 680-93.

[43] Zepeda, S. J. (2006). Cognitive dissonance, supervision, and administrative team conflict. International Journal of Educational Management, 20(3), 224-232. 